GRASAS Y ACEITES 67 (1)

January-March 2016, e114

ISSN-L: 0017-3495

doi: http://dx.doi.org/10.3989/gya.0378151

\title{
Effect of Spanish style processing on the phenolic compounds and antioxidant activity of Algerian green table olives
}

\author{
S. Mettouchi ${ }^{\mathrm{a}}$, R. Sacchi ${ }^{\mathrm{b}}$, Z.E.D. Ould Moussa ${ }^{\mathrm{a}}$, A. Paduano ${ }^{\mathrm{b}}$, M. Savarese ${ }^{\mathrm{c}}$ and A. Tamendjari ${ }^{\mathrm{a}, \bigotimes}$ \\ ${ }^{a}$ Laboratoire de Biochimie Appliquée, Faculté des Sciences de la Nature et de la Vie, Université de Bejaia, 06000, Algérie \\ ${ }^{b}$ Laboratory of MolecularGastronomy, Faculty di Agraria, UniversitaDegliStudi Di Napoli Federico II. Naples, Italy \\ ${ }^{\circ}$ CRIOL, Centro Ricerche per l'Industria Olearia, c/o Industria Olearia Biagio Mataluni; \\ via Badia, zona industriale, 82016 Montesarchio (BN), Italy \\ ${ }^{\circledR}$ Corresponding author: abderezakt@yahoo.fr
}

Submitted: 29 March 2015; Accepted: 06 July 2015

\begin{abstract}
SUMMARY: The study was carried out on seven Algerian olive cultivars to report the effect of Spanish style processing on individual and total phenolic compounds and the changes that occur in antioxidant capacity. The results indicate that the treatment leads to losses in phenolic contents which are cultivar dependent. Sigoise is the least affected variety (12.25\%) and Azzeradj from Seddouk the most affected one (94.80\%). The phenolic profile shows drastic changes after processing. Hydroxytyrosol is dominant in processed olives $\left(14.42-545.42 \mathrm{mg} \cdot 100 \mathrm{~g}^{-1}\right)$ while oleuropein is the major phenolic compound in fresh olives $\left(994.27 \mathrm{mg} \cdot 100 \mathrm{~g}^{-1}\right)$. As a consequence to the loss in phenolic content, substantial reductions in the antioxidant activities of the extracts are noted. They are estimated to be $13.12-92.75 \%$ in scavenging activity against the DPPH radical, $37.78-93.98 \%$ in reducing capacity, $59.45-97.94 \%$ in the hydrogen peroxide radical and $7.26-51.66 \%$ in the inhibition bleaching of $\beta$-carotene. Among the processed varieties, only Sigoise presented a positive value of RACI (relative antioxidant capacity index).
\end{abstract}

KEYWORDS: Antioxidant activity; Phenolic compounds; RACI; Spanish style processing; Table olives

RESUMEN: Efecto del procesamiento sobre el contenido fenólico y la actividad antioxidante de aceitunas verdes de mesa argelinas. El estudio se llevó a cabo con siete variedades de aceitunas argelinas y se investigó el efecto de la elaboración al estilo español sobre los compuestos fenólicos individuales y totales; así como los cambios que se producen en la capacidad antioxidante. Los resultados obtenidos muestran que el procesamiento conduce a pérdidas en el contenido fenólico, lo cual es dependiente de la variedad. Sigoise es la variedad menos afectada (12.25\%) y Azzeradj de Seddouk la más (94.80\%). El perfil fenólico muestra cambios drásticos después de su procesamiento. El hidroxitirosol es el polifenol predominante en aceitunas procesadas $\left(14.42-545.42 \mathrm{mg} \cdot 100 \mathrm{~g}^{-1}\right)$, mientras que la oleuropeína es el compuesto fenólico mayoritario en las aceitunas frescas $\left(994.27 \mathrm{mg} \cdot 100 \mathrm{~g}^{-1}\right)$. En consonancia con la pérdida en estos polifenoles, se detectaron reducciones sustanciales de la actividad antioxidante de los extractos. Se estima en 13.12 a $92.75 \%$ la actividad de eliminación de radicales DPPH 37.78-93.98\% en la reducción de la capacidad, 59.45 a 97.941\% en el radical peróxido de hidrógeno y 7.26-51.66\% en la inhibición de blanqueo del $\beta$-caroteno. Entre las variedades procesadas, sólo Sigoise presentó un valor positivo de RACI (Indice Relativo de Capacidad Antioxidante).

PALABRAS CLAVE: Aceitunas de mesa; Actividad antioxidante; Compuestos fenólicos; Estilo español de procesamiento; RACI

Citation/Cómo citar este artículo: Mettouchi S, Sacchi R, Ould Moussa ZED, Paduano A, Savarese M, Tamendjari A. 2016. Effect of Spanish style processing on phenolic compounds and antioxidant activity of Algerian green table olives. Grasas Aceites 67 (1): e114. doi: http://dx.doi.org/10.3989/gya.0378151.

Copyright: (C) 2016 CSIC. This is an open-access article distributed under the terms of the Creative Commons Attribution-Non Commercial (by-nc) Spain 3.0 Licence. 


\section{INTRODUCTION}

Table olives (Olea europaea) and olive oil are the main constituents of the Mediterranean diet. According to the statistical data (IOC, 2013), the worldwide production of table olives is estimated at more than 2.3 million tons (2013-2014 season). The Algerian production is on the rise, from 67.600 tonnes (average of 2001-2006) to 139.700 tonnes (2007-2013). With this production, Algeria contributes with 3.8 and $6 \%$, respectively, to world production. Table olives possess important biological proprieties, linked to their predominance in monounsaturated fat contents, and to antioxidant compounds like phenolics and tocopherols which have health benefits (Bianchi, 2003). Phenolic compounds have been shown to beneficially alter lipid composition, platelet and cellular function, as well as reduce oxidative damage and inflammation (Cicercale et al., 2010). Soni et al. (2006) reported the action of olive pulp extract on gastrointestinal disorders due to their antibacterial activity.

Several factors are known to affect the qualitative and quantitative phenolic profiles of table olives. These bioactive compounds are closely affected by cultivar (Vinha et al., 2005), degree of maturation (Malheiro et al., 2011), growing conditions (Marsilio et al., 2006), fruit size (Amiot et al., 1990) and processing methods (Sahan et al., 2013).

Olives cannot be consumed directly after harvest due to their extreme bitterness and they must undergo various processes. Three kinds of table olives are of economic importance in the international market: Spanish style green olives in brine, Greek style naturally black olives in brine, and California black ripe olives. Spanish style green olives or "alkali-treated green olives in brine" are the most widely distributed (El Khaloui and Nouri, 2007).

Many studies have been carried out regarding the influence of different processing methods of table olives on the levels of total and single phenolics (Romero et al., 2004; Pereira et al., 2006), but very few of them (Ben Othman et al., 2009) have been aimed at assessing the impact of this processing on the antioxidant capacity of the fruits. However, to our knowledge, no studies have been carried out about changes induced by Spanish style processing on Algerian green table olives. Therefore, this study is undertaken to investigate the evolution of phenolic compounds after Spanish style processing and to evaluate the result that those changes have on the antioxidant capacity of the finished product in order to determine the effect of this kind of processing on Algerian olive cultivars.

\section{MATERIAL AND METHODS}

\subsection{Plant material}

Olive fruits of seven Algerian cultivars: Azzeradj from Seddouk, Gordal, Sevilla, Sigoise, Taffahi, Bouchouk and Azzeradj from Tazmalt were harvested in October, 2012, at the green maturation stage. Four trees were selected and tagged and the olive fruits were hand-picked from different parts of the olive tree. After sorting and sizing, three kilograms of olives per variety were used.

\subsection{Processing}

Olives were debittered in an alkali solution $\left(15 \mathrm{~g} \cdot \mathrm{L}^{-1}\right)$ during 8 to12 $\mathrm{h}$ until the lye had penetrated two thirds of the pulp. Three washing waters are more than sufficient (twice for $4 \mathrm{~h}$ and once for $12 \mathrm{~h}$ ) to eliminate excess alkali. Then, the olives were fermented in brine $(8 \% \mathrm{NaCl})$ where a lactic fermentation reduces the $\mathrm{pH}$ to 4.5 .

Samples of fresh and processed olives were freeze-dried at $-58^{\circ} \mathrm{C}$ (Christ, Alpha 1-4 LD plus, Osterode am Harz, Germany), ground in electric blender (IKA model A 11 B, Staufen, Germany) and stored at $-18^{\circ} \mathrm{C}$ until analysis.

\subsection{Analysis of phenolic compounds}

\subsubsection{Extraction}

Phenolic compounds were extracted according to Mc Donald et al. (2001). Freeze dried olive pulps $(5 \mathrm{~g})$ were homogenized in $25 \mathrm{~mL}$ of methanol/water $(80: 20, v / v)$. The residue was extracted twice; extracts were combined, and washed with hexane. The extracts were filtered, and then kept cold until analysis.

\subsubsection{Total phenolic compounds}

The total phenolic content of the extracts was determined with Folin Ciocalteu reagent according to Borzello et al. (2000). Total phenol values were expressed as mg gallic acid equivalents per $100 \mathrm{~g}$ Dry Weight (mg GAEq $100 \mathrm{~g}^{-1} \mathrm{DW}$ ).

\subsubsection{HPLC separation and identification of phenolic compounds}

The presence and amount of phenolic compounds in the olive extracts were studied by reversed phase HPLC analysis using a binary gradient elution. The analysis was performed by reversed phase HPLC on a LC-10ADVP Shimadzu (Milan, Italy) liquid chromatography equipped with an SPD M10AVP diode array detector (Shimadzu). The chromatographic separation was achieved on a Spherisorb S5 ODS-3 (250 $\mathrm{mm} \times 4.6 \mathrm{~mm}$ i.d.) reversed-phase column (Phenomenex, Macclesfield, UK). The solvent system used was a gradient of solvent A (water: trifluoroacetic acid, 97:3, v/v), and solvent $B$ (acetonitrile: methanol, 80:20, v/v). A step gradient from 5\% to $98 \%$ B ( $45 \mathrm{~min}$ ) was applied at a flow rate of $1 \mathrm{~mL} \cdot \mathrm{min}^{-1}$. Peak quantification was carried out at $279 \mathrm{~nm}$. The main phenolic compounds were identified by comparison 
with relative retention times of pure compounds, when available, or by comparing the relative elution order and UV spectra with those reported in the literature (Brenes et al., 2000; Rovellini and Cortesi, 2002). The identity of each peak was confirmed by LC-MS, performed on an LC-10AD VP Shimadzu (Milan, Italy) liquid chromatograph on-line with an LCMS-2010EV Shimadzu (Milan, Italy) mass spectrometer, equipped with an electrospray ionization (ESI) interface. A Discovery HS C18 column $(5 \mu \mathrm{m}$, $150 \mathrm{~mm} \times 2.1 \mathrm{~mm}$ i.d., Supelco, St. Louis, MO, USA), at a flow rate of $0.35 \mathrm{~mL} \cdot \mathrm{min}^{-1}$, was used. The solvent system used was a gradient of solvent A (water+formic acid $0.25 \%$ ), and solvent $B$ (methanol+formic acid $0.25 \%$ ), with a step gradient from $5 \%$ to $55 \%$ B (45 $\mathrm{min})$. The ESI mass spectra $(\mathrm{m} / \mathrm{z} 60-900)$ in the negative ion mode were obtained under the following conditions: interface voltage $4 \mathrm{kV}$; nebulizer gas flow $1.5 \mathrm{~L} \cdot \mathrm{min}^{-1}$; block heater temperature $250^{\circ} \mathrm{C}$; curved desolvation line temperature and voltage of $300^{\circ} \mathrm{C}$ and $-5 \mathrm{~V}$, respectively; Q-Array voltage $0 \mathrm{~V} \mathrm{DC}$ and $150 \mathrm{~V}$ RF; detector voltage $1.5 \mathrm{kV}$. Some operating parameters (interface voltage and Q-Array voltage) were then modified in order to obtain a moderate fragmentation of the de-protonated molecular ions: an interface voltage of $5 \mathrm{kV}$ and a Q-Array voltage of $-50 \mathrm{~V}$ DC and $150 \mathrm{~V}$ RF were used (Savarese et al., 2007).

\subsection{Antioxidant activity}

\subsubsection{Reducing power}

The Ferric Reducing Power of the extracts was measured as reported by Zhan et al. (2006) using ferric chloride. The absorbance was then measured at $700 \mathrm{~nm}$ and the reducing power was expressed as $\mathrm{mg}$ quercetin, butylated hydroxyanisole and butylated hydroxytoluene equivalents per $100 \mathrm{~g}$ Dry Weight (mg QE, BHAEq and BHTEq $100 \mathrm{~g}^{-1} \mathrm{DW}$ ).

\subsubsection{DPPH free radical scavenging activity}

The procedure reported by Boskou et al., (2006) was adapted. An aliquot of the appropriate dilution of the extract $(0.5 \mathrm{~mL})$ was added to a 1,1-Diphenyl2-picryl-hydrazyl (DPPH) solution (2 mL) and kept in the dark for $30 \mathrm{~min}$. The absorbance was measured at $515 \mathrm{~nm}$ and the antiradical activity was expressed as mg quercetin and trolox equivalents per $100 \mathrm{~g}$ Dry Weight (mgQEq andTEq $\left.\cdot 100 \mathrm{~g}^{-1} \mathrm{DW}\right)$.

\subsubsection{Hydrogen peroxide radical scavenging assay}

The hydrogen peroxide radical scavenging activity was determined according to Hemalatha et al. (2013), the absorbance was measured at $230 \mathrm{~nm}$ after $10 \mathrm{~min}$ of incubation at $37{ }^{\circ} \mathrm{C}$. The percentage of hydrogen peroxide scavenging is calculated as follows:
\% scavenged $\mathrm{H}_{2} \mathrm{O}_{2}=\left(\mathrm{A}_{\mathrm{C}}-\mathrm{A}_{\mathrm{T}}\right) / \mathrm{A}_{\mathrm{C}} * 100$

Where: $A_{c}$ is the absorbance of the control and $\mathrm{A}_{\mathrm{T}}$ is the absorbance of the test.

\subsection{4. $\beta$-Carotene bleaching assay}

The effect of extracts on the $\beta$-carotene- linoleic acid emulsion was determined by applying the method reported by Nsimba et al. (2008). The absorbance of the tested samples was repeatedly measured every $15 \mathrm{~min}$ at $470 \mathrm{~nm}$. The total antioxidant activity was calculated based on the following equation:

$\% A A=\left[1-\left(\frac{A_{0}-A_{t}}{A_{00}-A_{0 t}}\right)\right]^{*} 100$

Where: $\mathrm{AA} \%$ is antioxidant activity, $\mathrm{A}_{0}$ and $\mathrm{A}_{\mathrm{t}}$; emulsion absorbance at $\mathrm{t}=0$ and after incubation time $\mathrm{t}(\mathrm{t}=105 \mathrm{~min}), \mathrm{A}_{00}$ and $\mathrm{A}_{0 \mathrm{t}}$ : absorbance values for negative control at $\mathrm{t}=0$ and after the same incubation time.

\subsection{Statistical analysis}

All experiments were conducted in triplicate and a statistical analysis was done using Statistica 5.5 with the analysis of variance (ANOVA/MANOVA) to determine the significant differences at a level of confidence of $(\mathrm{P}<0.05)$. Correlation coefficients were calculated using the Pearson coefficient.

\section{RESULTS AND DISCUSSION}

\subsection{Phenolic compounds}

\subsubsection{Total phenolic content}

Phenolic contents (Table 1) differ significantly $(\mathrm{p}<0.05)$ among the investigated olive cultivars, and between fresh and processed olives for the same cultivar. Their content are higher in fresh olives (346 mg $\cdot 100 \mathrm{~g} \mathrm{~g}^{-1}$ in Bouchouk to $2406 \mathrm{mg} \cdot 100 \mathrm{~g}^{-1}$ in Azzeradj from Seddouk), than in processed ones (124 mg.100 g $\mathrm{g}^{-1}$ in Azzeradj from Seddouk to $1688 \mathrm{mg} \cdot 100 \mathrm{~g}^{-1}$ in Sigoise).

The results obtained for fresh olives are similar to those obtained for Portuguese cultivars (Pereira et al. 2006), Tunisian cultivars (Ben Othman et al. 2009), and Italian cultivars Piscopo et al. (2014). However, processed olives contained higher amounts of phenolic compounds than those studied by Blekas et al. (2002) and similar contents to those reported by Ben Othman et al. (2009).

A drastic decrease in phenolic content was noted after processing. Losses in those compounds differ largely among the cultivars, from $12.25 \%$ (Sigoise) 


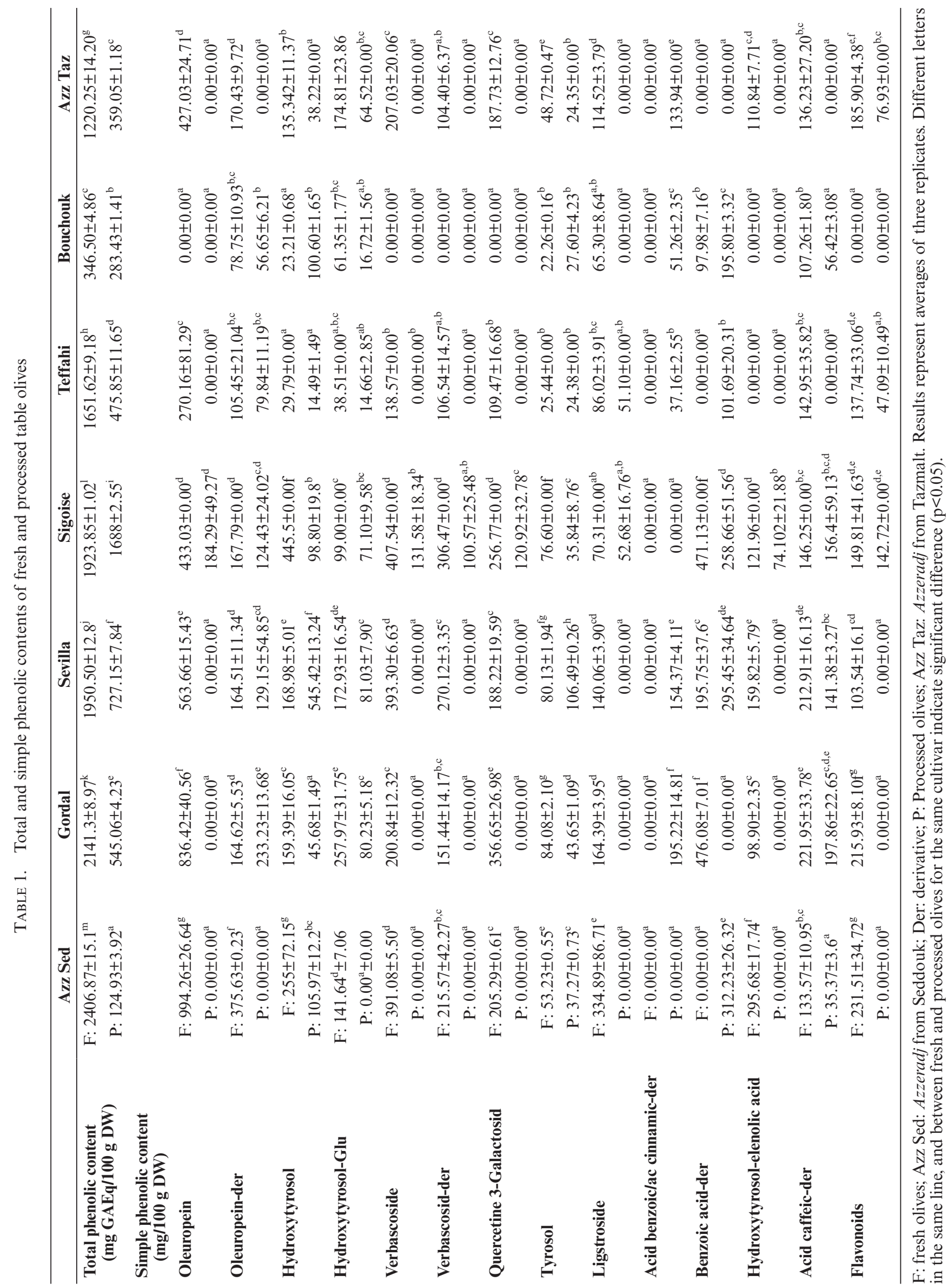


to $94.80 \%$ (Azzeradj from Seddouk). This trend confirms that processing influence phenolic behavior differently between cultivars according to their phenolic profile. In fact, the diffusion of phenols from olive pulp to brine depends on cultivar characteristics, fruit skin, permeability, type of phenols present in the olives and their ability to diffuse outside the fruit (Kiai and Hafidi, 2014).

\subsubsection{HPLC identification of phenolic compounds}

The HPLC analysis of phenolic compounds (Table 1) showed that olive flesh revealed different phenolic compound compositions for the seven analyzed cultivars with a drastic difference between fresh and processed olives.

The main phenolic compound detected in fresh olives was oleuropein; its proportion ranged from $25.43 \%$ (Sevilla) to $39.10 \%$ (Gordal). The oleuropein level was variety dependant and Azzeradj from Seddouk presented the highest amount $\left(994.27 \mathrm{mg} \cdot 100 \mathrm{~g} \mathrm{~g}^{-1}\right)$, while in Bouchouk this compound was not detected. These significant differences could be explained by the cultivated variety, cultivars with large fruit size (data not shown) have higher amounts of oleuropein (Azzeradj from Seddouk and Gordal) than the small size ones (Sigoise and Bouchouk) as reported previously by Amiot et al. (1990). The analyzed cultivars showed higher amounts of oleuropein compared to Tunisian cultivars (Ben Othman et al., 2009) and Italian cultivars (Piscopo et al., 2014). The results confirmed the effect of cultivar and geographical origin on the phenolic content of olives.

Verbascoside was the second most abundant phenolic compound; its values ranged from 391.08 to $407.548 \mathrm{mg} \cdot 100 \mathrm{~g}^{-1}$ for Azzeradj from Seddouk and Sigoise, respectively. The amounts of ligstroside vary between $65.30 \mathrm{mg} \cdot 100 \mathrm{~g}^{-1}$ (Bouchouk) and $334.89 \mathrm{mg} \cdot 100 \mathrm{~g}^{-1}$ (Azzeradj from Seddouk).

Similarly to the evolution of oleuropeine, verbascoside and ligstroside contents showed a decline in processed olives; their contents were under quantification limits in processed olives for the majority of cultivars, excepted for Sigoise. The results obtained confirm previous data (Boskou et al., 2006; Kiai and Hafidi, 2014) which reported a decrease in oleuropein and verbascoside contents, similarly to an increase in hydroxytyrosol. Processing according to Spanish style causes hydrolysis of phenol complexes due to $\mathrm{NaOH}$ treatment, leading to the liberation of simple phenols. Tyrosol showed a slight decrease as well after processing. This observation was not in agreement with the findings of Sahan et al. (2013) who observed an increase in the tyrosol content arising from ligstroside hydrolysis. In addition, fresh olives are rich in quercetin -3 galactoside $\left(109.47 \mathrm{mg} \cdot 100 \mathrm{~g}^{-1}\right.$ in Teffahi to $356.65 \mathrm{mg} \cdot 100 \mathrm{~g}^{-1}$ in Gordal). These values are much higher than the amount reported by Piscopo et al. (2014) in
Italian cultivar; with the exception of Bouchouk $\left(0.00 \mathrm{mg} \cdot 100 \mathrm{~g}^{-1}\right)$.

In processed olives, the first major phenolic compound was hydroxytyrosol. The highest content was recorded for Sevilla $\left(545.42 \mathrm{mg} \cdot 100 \mathrm{~g}^{-1}\right.$ DW equivalent to $109 \mathrm{mg} \cdot 100 \mathrm{~g}^{-1} \mathrm{FW}$ ), this result is higher than that of Sahan et al., (2013) (26.45 mg $100 \mathrm{~g}^{-1}$ FW). The lowest level was observed in Teffahi $\left(14.49 \mathrm{mg} \cdot 100 \mathrm{~g}^{-1}\right)$. It is known that hydroxytyrosol derives from the hydrolysis of oleuropein and verbascoside. An increase in the content of this compound was observed only in Sevilla and Bouchouk varieties. In contrast, for other varieties, a decrease was noted. This might be explained by the diffusion of this polar compound to the brine, or its oxidation during de-bittering (Pasqualone et al., 2014).

Caffeic acid, which is derived from the hydrolysis of verbascoside, was not detected in processed olives. Rodriguez et al. (2008) demonstrated that phenolic acids as caffeic, p-coumaric and ferulic acids are metabolized by L-plantarum, which contain a phenolic acid decarboxylase, to their corresponding vinyl derivatives. Romero et al. (2004) showed that simple phenolic compounds are converted by lactic acid bacteria and de-polymerized.

\subsection{Antioxidant activity}

\subsubsection{Reducing power}

The ferric reducing power of the phenolic extracts of fresh and processed olives are represented in Table 2 (The three standards used recorded the same level of significance). The fresh olives of Azzeradj from Seddouk exhibited the strongest reducing capacity (4531.90 mg QEq/100 g; $7784.4 \mathrm{mg}$ BHAEq $100 \mathrm{~g}^{-1}$; $9180.82 \mathrm{mg} \mathrm{BHTEq} \cdot 100 \mathrm{~g}^{-1}$ ) while Bouchouk recorded the lowest one $\left(522.45 \mathrm{mg} \mathrm{QEq} \cdot 100 \mathrm{~g} \mathrm{~g}^{-1} ; 887.40 \mathrm{mg}\right.$ BHAEq $\left.\cdot 100 \mathrm{~g}^{-1} ; 1058.66 \mathrm{mg} \mathrm{BHTEq} \cdot 100 \mathrm{~g}^{-1}\right)$.

Processing caused a decrease in the reducing capacity of extracts. The values ranged from 283.36 QEq $100 \mathrm{~g}^{-1}, 486.72 \mathrm{BHAEq} \cdot 100 \mathrm{~g}^{-1}, 574.85 \mathrm{mg}$ BHTEq $100 \mathrm{~g}^{-1}$ (Azzeradj from Seddouk) to2316.28 mg QEq·100 g ${ }^{-1}, 3978.64 \mathrm{mg}$ BHAEq·100 $\mathrm{g}^{-1}$, $4687.47 \mathrm{mg}$ BHTEq $100 \mathrm{~g}^{-1}$ (Sigoise). So that, decreases in reducing power after processing were estimated to $37.78 \%$ (Sigoise), $52.42 \%$ (Sevilla), $55.25 \%$ (Azzeradj from Tazmalt), 68.39\% (Teffahi), 76.09\% (Gordal) and 93.98\% (Azzeradj from Seddouk).

The results showed that a reduction in reducing power is related to a loss in phenolic content. A significante correlation $(\mathrm{r}=0.98)$ (Table 3$)$ was obtained between the two parameters. Azzeradj from Seddouk recorded the highest phenol content loss $(9.80 \%)$ and showed the highest reducing capacity loss $(93.98 \%)$. In contrast, Sigoise, in which the phenolic content was more preserved, showed the lowest reducing power reduction $(37 \%)$. No change is noted in reducing power for 


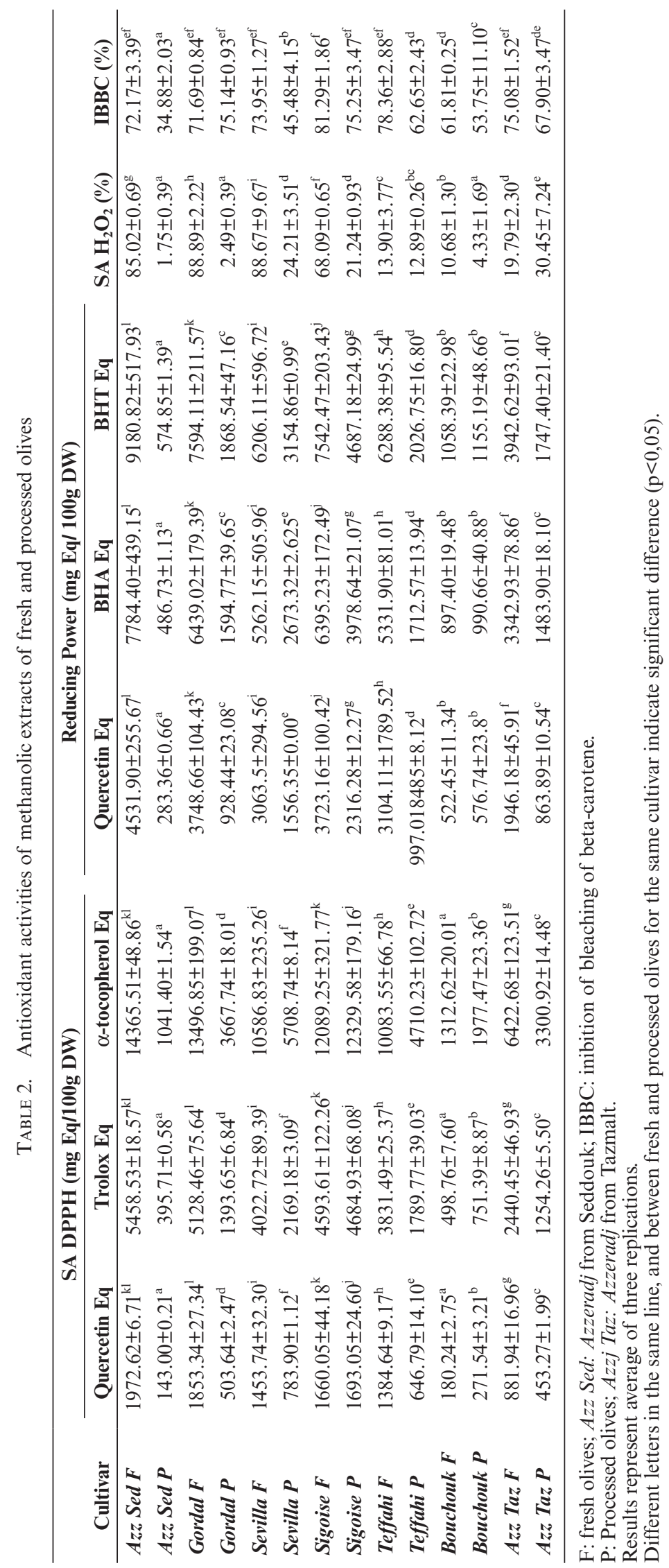


Effect of Spanish style processing on the phenolic compounds and antioxidant activity of Algerian green table olives $\bullet$

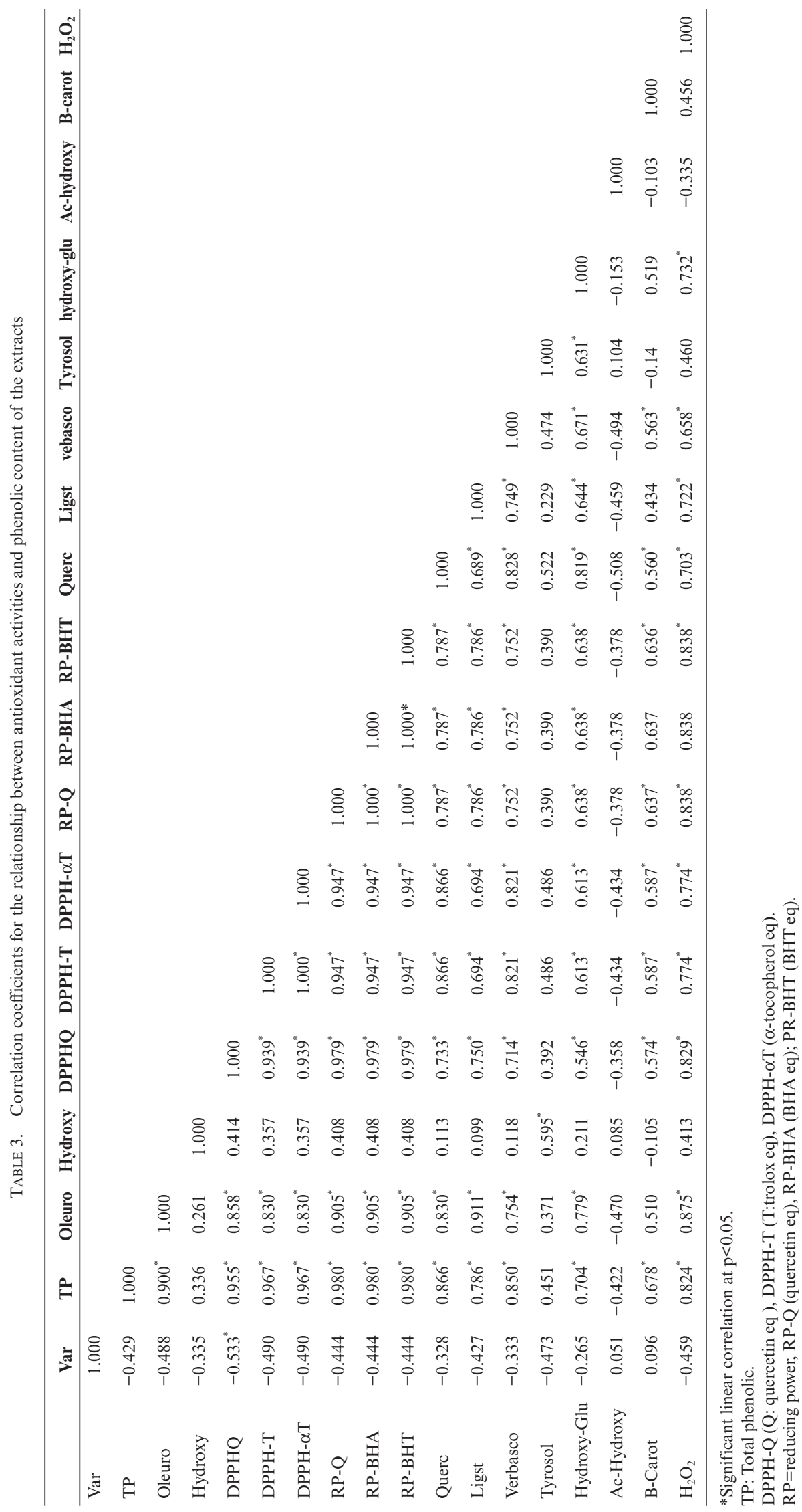


Bouchouk, which is probably due to its preservation of phenolic compounds.

The potential anti-oxidant index (PAOXI) values of extracts are given in Table 4. Lower PAOXI indicates a lower phenolic content and a better efficiency (Sun and Tanumihardjo, 2007). Our results indicated that all the samples (fresh and processed olives) are efficient because of their PAOXI values of $<1$. However, the differences noted among PAOXI values might be related to the differences in the phenolic profile of each cultivar. The five varieties processed according to the Spanish style exhibited a better efficiency than their corresponding fresh olives. They are classified as: Azzeradj from Tazmalt $=$ Azzerad $j$ from Seddouk $>$ Sevilla $>$ Teffahi $>$ Bouchouk. This indicates that the processing had a positive effect on phenolic profiles (in some cultivars), which permits the transformation of glycoside to aglycone forms, which is more effective.

\subsubsection{DPPH radical scavenging activity}

The scavenging capacity of the extracts (Table 2) showed no statistically significant difference between Gordal, Azzeradj from Seddouk and Sigoise for fresh olives. These cultivars exhibited the highest scavenging capacities. Differences noted among the other varieties should certainly be related to the differences in the phenolic profiles of cultivars.

The effect of processing on scavenging capacity differs among the cultivars; as a consequence

TABLE 4. PAOXI values of extracts corresponding to reducing power, scavenging activity and inhibition bleaching of $\beta$-carotene

\begin{tabular}{llll}
\hline & RP & SAH $_{2} \mathbf{O}_{2}$ & IBBC \\
\hline Azzsed & F: $0.514^{\mathrm{d}}$ & F: $0.286^{\mathrm{b}}$ & F: $0.336^{\mathrm{g}}$ \\
& P: $0.429^{\mathrm{a}}$ & P: $0.626^{\mathrm{c}}$ & P: $0.035^{\mathrm{a}}$ \\
Gordal & F: $0.560^{\mathrm{e}}$ & F: $0.237^{\mathrm{a}, \mathrm{b}}$ & F: $0.299^{\mathrm{f}}$ \\
& P: $0.597^{\mathrm{f}}$ & P: $2.209 \mathrm{f}$ & P: $0.072^{\mathrm{b}}$ \\
Sevilla & F: $0.594^{\mathrm{f}}$ & F: $0.208^{\mathrm{a}}$ & F: $0.263^{\mathrm{e}}$ \\
& P: $0.468^{\mathrm{b}}$ & P: $0.317^{\mathrm{b}}$ & P: $0.161^{\mathrm{c}}$ \\
\multirow{3}{*}{ Sigoise } & F: $0.584^{\mathrm{e}, \mathrm{f}}$ & F: $0.319^{\mathrm{b}}$ & F: $0.267^{\mathrm{e}}$ \\
& P: $0.805 \mathrm{~h}$ & P: $0.858^{\mathrm{d}}$ & P: $0.248^{\mathrm{e}}$ \\
\multirow{4}{*}{ Teffahi } & F: $0.527^{\mathrm{d}}$ & F: $1.053^{\mathrm{e}}$ & F: $0.210^{\mathrm{d}}$ \\
& P: $0.480^{\mathrm{b}, \mathrm{c}}$ & P: $0.369^{\mathrm{b}}$ & P: $0.076^{\mathrm{b}}$ \\
& F: $0.648^{\mathrm{g}}$ & F: $0.323^{\mathrm{b}}$ & F: $0.055^{\mathrm{a}, \mathrm{b}}$ \\
Azz Taz & P: $0.505^{\mathrm{c}, \mathrm{d}}$ & P: $0.575^{\mathrm{c}}$ & P: $0.054^{\mathrm{a}, \mathrm{b}}$ \\
& F: $0.632^{\mathrm{g}}$ & F: $0.578^{\mathrm{c}}$ & F: $0.161^{\mathrm{c}}$ \\
& P: $0.419^{\mathrm{a}}$ & P: $0.106^{\mathrm{a}}$ & P: $0.054^{\mathrm{b}}$ \\
\hline
\end{tabular}

F: fresh olives P: Processed olives.

RP: Reducing Power $\mathrm{SAH}_{2} \mathrm{O}_{2}$ : Scavenging activity against $\mathrm{H}_{2} \mathrm{O}_{2}$ IBBC: Inhibition Bleaching of $\beta$-carotene.

Different letters in the same column indicate significant difference $(\mathrm{p}<0.05)$. of the decline in phenolic content, a reduction was noted for six cultivars with remarkable differences in loss percentages: $92.75 \%$ (Azzeradj from Seddouk), 72.82\% (Gordal), 53.28\% (Teffahi), 48.60\% (Azzeradj from Tazmalt), $46.1 \%$ (Sevilla) and only $13.12 \%$ for Sigoise, which was the best efficient extract among processed olives. This in agreement with the results of Sahan et al. (2013) for the Gemlik cultivar. On the contrary, Bouchouk showed an increase (33.57\%) in antioxidant activity after processing, which can be attributed to the increase in cinnamic acid derivatives $(100 \%)$, hydroxytyrosol $(76.93 \%)$, benzoic acid derivatives $(49.96 \%)$ and tyrosol (19.35\%), confirming that the antioxidant effect does not depend only on the phenolic content but also on the phenolic profile. On the other hand, Brenes and de Castro (1998) claimed that the antioxidant activity of hydroxytyrosol is higher than that of oleuropein. Velkov et al. (2007) ranked the phenols of green olives according to their scavenging activity as: dihydrocaffeic acid $>$ hydroxytyrosol $>$ caffeic acid $>$ oleuropein.

According to the Folin Ciocalteu assay, Gordal showed a higher phenolic content than Teffahi, while it presented the lowest antioxidant capacity; these contradictory results reflect the influence of the nature of phenolic compound on antioxidant activity.

A graphic representation $\%$ DPPH inhibition $=f$ $\left(\mathrm{C}\left(\mathrm{mg} \cdot \mathrm{mL}^{-1}\right)\right)$ revealed a perfect linearity for all samples $(0.993 \leq \mathrm{r} \leq 0.997)$ (data not shown) which indicates that the extract scavenging effect on DPPH radical increases with increasing concentrations. The scavenging capacity of fresh olives according to the effective concentrations $\left(\mathrm{EC}_{50}\right)$ (Table 2) followed the order: Azzeradj from Seddouk $>$ Sevilla $>$ Sigoise $>$ Gordal $>$ Teffahi $>$ Azzeradj from Tazmalt $>$ Bouchouk. For the processed olives the order was: Sigoise $>$ Sevilla $>$ Gordal $>$ Teffahi $>$ Azzeradj from Tazmalt $>$ Bouchouk $>$ Azzeradj from Seddouk. The results obtained for fresh olives (except for Bouchouk and Azzeradj from Tazmalt) are in good agreement with those of Arslan and Ozcan (2011) and Malheiro et al. (2011). Otherwise, Ilias et al. (2011) revealed an effective concentration two times lower for Sigoise from Tlemcen; this can be related to differences in composition linked to the geographical origin (Vinha et al., 2005).

The effective concentration $\left(\mathrm{EC}_{50}\right)$ of extracts exhibited an inverse relationship with phenol contents, showing a significant negative correlation $(r=-0.772)$. Phenolic compounds of olive extracts are good hydrogen donors.

Sigoise processed olives were more effective in scavenging DPPH radical, showing smaller $\mathrm{EC}_{50}$ values $(0.38 \mathrm{mg} / \mathrm{mL})$ than those found by Sousa et al. (2008) for the Portuguese Alcaparra variety. These results confirm the superiority of Sigoise processed cultivar in antioxidant activity, which can be related to its higher quercetine-3 galactosid and caffeic acid contents than other processed 
olives. The high $\mathrm{EC}_{50}$ values obtained for Bouchouk and Azzeradj from Seddouk were justified by their polyphenol contents.

\subsubsection{Hydrogen peroxide radical scavenging assay $\left(\mathrm{SAH}_{2} \mathrm{O}_{2}\right)$}

Inhibition percentages of hydrogen peroxide in fresh and processed green olives (Table 2) at a concentration of $3.571 \mathrm{mg} \cdot \mathrm{mL}^{-1}$ showed significant differences $(p<0.05)$. Fresh olives of the Gordal and Sevilla varieties exhibited the strongest scavenging activities $(88.89$ and $88.67 \%)$ similar to that of the Chemlal cultivar analyzed by Nadour et al. (2012) but at a concentration of $0.25 \mathrm{mg} \cdot \mathrm{mL}^{-1}$. Bouchouk exerts the lowest one (10.68\%).

Losses in scavenging activities after processing were estimated to be 97.94, 97.19, 72.69, 68.8 and $59.45 \%$, respectively, for Azzeradj from Seddouk, Gordal, Sevilla, Sigoise and Bouchouk. After processing, Teffahi recorded statistically the same activity and Azzeradj from Tazmalt showed an increase of $35.0 \%$. This may be related to the formation of more effective phenols after processing, and mainly to the generation of phenolic acids $\left(133.94 \mathrm{mg} \cdot 100 \mathrm{~g}^{-1}\right.$ ) (hydroxycinnamic and hydroxybenzoic acid derivatives).

The antioxidant activity of flavonoids against $\mathrm{H}_{2} \mathrm{O}_{2}$ was not significant ( $\mathrm{r}=0.404$ ) (Table 3). However, if we consider separately fresh samples and processed samples, this coefficient was 0.814 and 0.361 , respectively. Thus, the loss in this coefficient estimated at 2.25 explains the negative effect of processing by Spanish style on the flavonoid contents of green olives.

Potential antioxidant index (PAOXI) values of the extracts (Table 4) confirmed losses in scavenging activities by the increase of PAOXI values for the cultivars Sevilla, Bouchouk, Azzeradj from seddouk, and Sigoise. Although Gordal showed a very low efficiency of its phenolic compounds, requiring the implication of more than two phenolic fractions to enrich by one scavenging activity unity. The PAOXI value obtained for Azzeradj from Tazmalt is in agreement with the increase in scavenging activity, recording the lowest PAOXI value among the studied cultivars.

\subsection{4. $\beta$ - carotene bleaching assay}

The percentages of inhibition bleaching of $\beta$-carotene (IBBC) for fresh and processed olive extracts at the concentration of $7.14 \mathrm{mg} \cdot \mathrm{mL}^{-1}$ are given in Table 2. No significant differences $(p \leq 0.05)$ were noted between fresh and processed olives except for Azzeradj from Seddouk and Sevilla. This indicates that the phenolic compounds of green olives (fresh and processed) react strongly in an organic medium, probably due to their partition coefficient.

Losses in antioxidant activity after processing varied according to the cultivar: Azzeradj from
Seddouk (51.66\%), Sevilla (38.5\%), Teffahi (20.04\%), Bouchouk (13.01\%), Azzerad from Tazmalt $(9.56 \%)$, Sigoise $(7.26 \%)$. However, an increase was recorded for Gordal which is probably due to the increase in phenolic acids, such as in cinnamic acid derivatives. Skoraand Cisowski (2003) postulated that phenolic acids are the weakest inhibitors in lipid peroxidation. Otherwise, contrary to the findings of Han et al. (2012), who reported a synergism action between flavonoids and $\beta$-carotene accordingly at the water/lipid interfaces, our results show a decline in flavonoid content and similar antioxidant activity after processing. A moderate correlation was established between $\beta$-carotene bleaching assay and total phenolics $(r=0.67)($ Table 3$)$, this means that lipid peroxidation inhibitory activity could be partially correlated to the phenolic content.

The PAOXI values obtained (Table 4) clearly showed that the majority of extracts had better activities in an emulsion medium than in an aqueous one. This may be explained by the "Polar paradox" phenomenon characterized by the accumulation of a polar antioxidant in the oil-water interface, thus protecting the lipids from oxidation (Hayes et al., 2011).

\subsubsection{Evaluation of table olive total antioxidant capacity}

To get a complete picture of the ranking of the antioxidant capacities of table olives, a relative antioxidant capacity index (RACI) was calculated by integrating the antioxidant capacity values generated from the different tests. RACI is the mean value of standard scores transformed from the initial data generated with different methods (Sun and Tanumihardjo, 2007). Results of the classification of samples (Figure 1) revealed the superiority of the fresh olives of Azzeradj from Seddouk in the totality of tests, giving a RACI value of +1.53 . The processed olives of the same variety present the lowest RACI value (-1.41). The results showed that among the processed olives, only Sigoise denoted a positive value of RACI.

\section{CONCLUSION}

In conclusion, the results revealed a significant influence of Spanish style processing on the phenolic compounds and antioxidant capacity of green table olives extracts of seven Algerian cultivars. This effect differs greatly among the cultivars; Sigoise is the most conservative variety and Azzeradj from Seddouk is the most dissipating one.

The results obtained for the antioxidant activity assessed by the four assays showed that among the studied cultivars, the fresh olives of the Azzeradj variety from Seddouk exhibited the highest phenolic content and exerted the strongest antioxidant activities, but they were also the most affected by the processing 


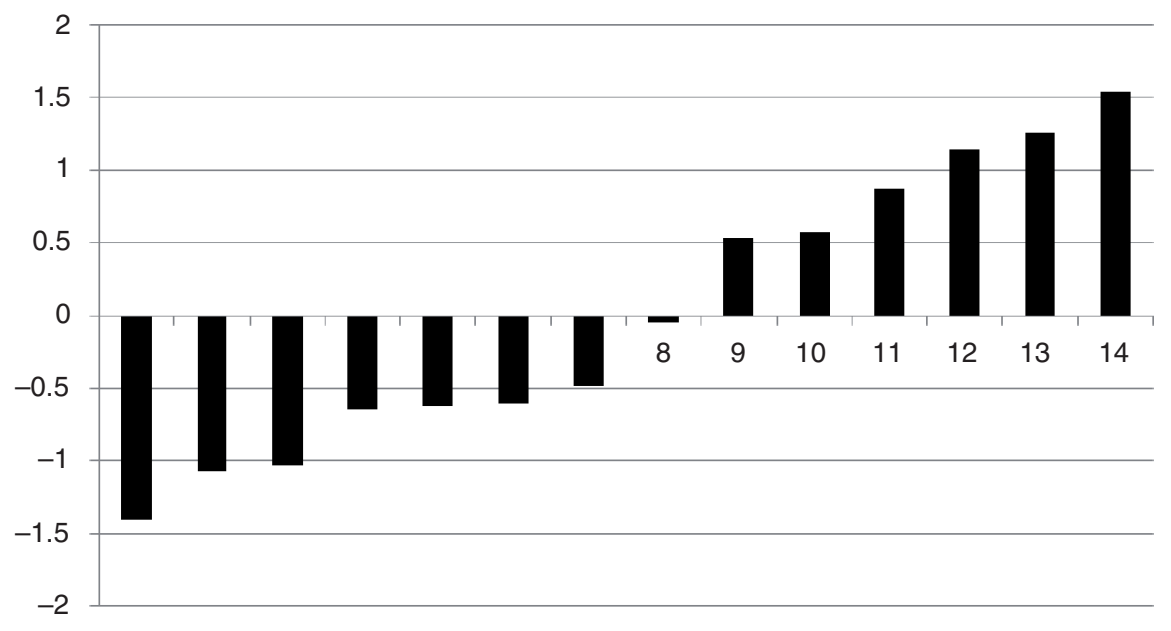

\author{
1: Azzeradj Seddouk Processed \\ 2: Bouchouk processed \\ 3: Bouchouk fresh \\ 4: Azzeradj from Tazmalt processed \\ 5: Gordal processed \\ 6: Teffahi processed \\ 7: Sevilla processed
}

\author{
8: Azzeradj Tazmalt fresh \\ 9: Sigoise processed \\ 10: Teffahi fresh \\ 11: Sevilla fresh \\ 12: Sigoise fresh \\ 13: Gordal fresh \\ 14: Azzeradj Seddouk fresh
}

FIGURE 1. Relative antioxidant capacity index (RACI) of extracts of fresh and processed olives.

treatment (loss of $94.80 \%$ in phenolic content), which caused a loss of 93.74, 92.75, 97.94, 51.66\% in reducing capacity, scavenging capacity against DPPH radical, hydrogen peroxide radical and in the bleaching test, respectively. Instead, Sigoise, the most representative cultivar of the Algerian Market, was the least affected by the processing. The antioxidant activity of processed olives recorded significant losses for the aqueous medium in contrast to the organic medium. Fresh olives of Azzeradj from Seddouk exhibited the highest RACI value, confirming their superiority in antioxidant capacity.

The data from this study show that olive extracts and mainly extracts of fresh olives of Azzeradj from seddouk may constitute a good source of healthy compounds. It would be interesting to use other methods of preparation that could preserve them.

As far as we know, this is the first report considering the antioxidant potential of Algerian green olive cultivars. Further studies are needed to focus on phenolic loss reduction as a result of Spanish style processing of green table olives.

\section{ACKNOWLEDGEMENTS}

The authors are grateful to the staff of ITAFV (Institut d'Arboriculture Fruitière et de la Vigne) Takerietz (Bejaia, Algeria) and the company of KHODJA \& CO Seddouk (Bejaia, Algeria ) for providing the samples.

\section{REFERENCES}

Amiot MJ, Friet A, Macheix J. 1986. Importance and evolution of phenolic compounds in olive during growth and maturation. J. Agric. Food Chem. 34, 823-826. http://dx.doi.org/10.1021/ jf00071a014.

Arslan D. 2012. Physico-chemical characteristics of olive fruits of Turkish varieties from the province of Hatay. Grasas Aceites 63, 158-166. http://dx.doi.org/10.3989/ gya.071611.

Arslan D, Schreiner M. 2012. Chemical characteristics and antioxidant activity of olive oils from Turkish varieties grown in Hatay province. Sci. Hortic. 144, 141-152. http://dx.doi. org/10.1016/j.scienta.2012.07.006.

Arslan D, Özcan MM. 2011. Phenolic profile and antioxidant activity of olive fruits of the Turkish variety "Sarıulak" from different locations. Grasas Aceites 62, 453-461. http:// dx.doi.org/10.3989/gya.034311.

Ben Othman N, Roblain D, Chammen N, Thonart P, Hamdi, M. 2009. Antioxidant phenolic compounds loss during the fermentation of Chétoui olives. Food Chem. 116, 662-669. http://dx.doi.org/10.1016/j.foodchem.2009.02.084.

Bianchi G. 2003. Lipids and phenols in table olives. Eur. J. Lipid Sci. Technol. 105, 229-242. http://dx.doi.org/10.1002/ ejlt.200390046.

Blekas G, Vassilakis C, Harizanis C, Tsimidou M, Boskou D-G. 2002. Biophenols in table olives. J. Agric. Food Chem. 50, 3688-3692. http://dx.doi.org/10.1021/jf0115138.

Borzillo A, Iannotta N, Uccella N. 2000. Oinotria table olives: quality evaluation during ripening and processing by biomolecular components. Eur. Food Res. and Technol. 212, 113-121.

Boskou G, Fotini N, Salta Chrysostomou S, Mylona A, Chiou A, Andrikopoulos NK. 2006. Antioxidant capacity and phenolic profile of table olives from the Greek market. Food Chem. 94, 558-564. http://dx.doi.org/10.1016/j.foodchem. 2004.12.005.

Brenes M, Hidalgo JH, Garcia A, Rios JJ, Garcia P, Zamora R. 2000. Pinoresinol and 1-acetoxypinoresinol, two new 
phenolic compounds identified in olive oil. J. Am. Oil Chem. Soc.77,715-720.http://dx.doi.org/10.1007/s11746000-0115-4.

Brenes M, de Castro A. 1998. Transformation of oleuropein and its hydrolysis products during Spanish-style green olive processing. J. Sci. Food Agric. 77, 353-358.

Cicerale S, Lucas L, Keast R. 2010. Biological Activities of Phenolic Compounds Present in Virgin Olive Oil. Int. J. Mol. Sci. 11, 458-479. http://dx.doi.org/10.3390/ijms11020458.

Dourtoglou VG, Mamalos A, Makris, DP. 2006. Storage of olives (Oleaeuropaea) under $\mathrm{CO} 2$ atmosphere: Effect on anthocyanins, phenolics, sensory attributes and in vitro antioxidant properties. Food Chem. 99, 342-349. http:// dx.doi.org/10.1016/j.foodchem.2005.07.051.

El Khaloui M, Nouri A. 2007. Procédé d'élaboration des olives de table à base des variétés Picholine Marocaine et Dahbia. Transfert Technol. Agric., 152, 1-4.

Han RM, Zhang JP, Skibsted LH. 2012. Reaction Dynamics of Flavonoids and Carotenoids as Antioxidants. Molecules 17, 2140-2160. http://dx.doi.org/10.3390/molecules17022140.

Hayes JE, Allen P, Brunton N, O'Grady MN, Kerry JP. 2011. Phenolic composition and in vitro antioxidant capacity of four commercial phytochemical products: Olive leaf extract (Oleaeuropaea L.), lutein, sesamol and ellagic acid. Food Chem. 126, 948-955. http://dx.doi.org/10.1016/j. foodchem.2010.11.092

Hemalatha A, Girija K, Parthiban C, Saranya C, Anantharaman P. 2013. Antioxidant properties and total phenolic content of a marine diatom, Naviculaclavata and green microalgae, Chlorella marina and Dunaliella salina. Adv. App. Sci. Res. 4, 151-157.

Ilias F, Kholkhal W, Gaouar N, Bekhechi C, Bekkara FA. 2011. Antioxidant potential of olive (Oleaeuropaea L.) from Algeria. J. Nat. Prod Plant Resour. 1, 29-35. http:// scholarsresearchlibrary.com/archive.html.

IOC (International Olive Council). 2013. Market Newsletter, No 76 - Octobre 2013, production d'olives de table, 1-6.

Kia H, Hafidi A. 2014. Chemical composition changes in four green olive cultivars during spontaneous fermentation. LWT-Food Sci. Technol. 57, 663-670. http://dx.doi.org/ 10.1016/j.lwt.2014.02.011.

Malheiro R, Sousa A, Casal S, Bento A, Pereira JA. 2011. Cultivar effect on the phenolic composition and antioxidant potential of stoned table olives. Food Chem. Toxicol. 49, 450-457. http://dx.doi.org/10.1016/j.fct.2010.11.023.

Marsilio V, d'Andria R, Lanza B, Russi F, Iannucci E, Lavini A. 2006. Effect of irrigation and lactic acid bacteria inoculants on the phenolic fraction, fermentation and sensory characteristics of olive (Oleaeuropaea L. cv. Ascolanatenera) fruits. J. Sci. Food Agric. 86, 1005-1013. http://dx.doi.org/ $10.1002 /$ jsfa. 2449.

McDonald S, Prenzler PD, Antolovich M, Robards K. 2001. Phenolic content and antioxidant activity of olive extracts. Food Chem. 73, 73-84. http://dx.doi.org/10.1016/S03088146(00)00288-0.

Nadour M, Michaud P, Moulti-Mati F. 2012. Antioxidant Activities of Polyphenols Extracted from Olive (Oleaeuropaea) of Chemlal Variety. Appl. Biochem. Biotechnol. 167, 1802-1810. http://dx.doi.org/10.1007/s12010-012-9633-8.

Nsimba RY, Kikuzaki H, Konishi Y. 2008. Antioxidant activity of various extracts and fractions of Chenopodium quinoa and Amaranthus spp. Seeds. Food Chem. 106, 760-766. http://dx.doi.org/10.1016/j.foodchem.2007.06.004

Pasqualone A, Nasti R, Montemurro C, Gomes T. 2014. Effect of natural style processing on the oxidative and the lipid fraction of d hydrolytic degradation of table olives. Food Control. 37, 99-103. http://dx.doi.org/10.1016/j.foodcont. 2013.09.038.

Pereira J-A, Pereira A-PG, Ferreira ICFR, Valenta P, Andrade PB, Seabra R, Estevinho L, Bento A. 2006. Table Olives from Portugal: Phenolic Compounds, Antioxidant Potential and Antimicrobial Activity. J. Agric. Food Chem. 54, 8425-8431. http://dx.doi.org/10.1021/jf061769j.

Piscopo A. De Bruno A. Zappia A. Poiana M. 2014. Antioxidant activity of dried green olives (Caroleacv.). LWT-Food Sci. Technol. 58, 49-54. http://dx.doi.org/10.1016/j.lwt. 2014.03.013.

Rodríguez H, Curiel JA, Landete JM, de las Rivas B, de Felipe FL, Gómez-Cordovés, C, Mancheño JM, Muñoz R. 2009. Food phenolics and lactic acid bacteria. Int. J. Food Microbiol. 132, 79-90. http://dx.doi.org/10.1016/j. ijfoodmicro.2009.03.025

Romero C, Brenes M, Yousfi K, Garcia P, García A, Garrido A. 2004. Effect of cultivar and processing method on the contents of polyphenols in table olives. J. Agric. Food Chem. 52 (3), 479-484. http://dx.doi.org/10.1021/jf0305251.

Rovellini P, Cortesi N. 2002. Liquid chromatography-mass spectrometry in the study of oleuropein and ligstroside aglycons in virgin olive oil: aldehydic, dialdehydic forms and their oxidized products. Riv. Ital. Sostanze Gr. 79, 1-14.

Sahan Y, Cansev A, Gulen H. 2013. Effect of Processing Techniques on Antioxidative Enzyme Activities, Antioxidant Capacity, Phenolic Compounds, and Fatty Acids of Table Olives. Food Sci. Biotechnol. 22, 613-620. http://dx.doi. org/10.1007/s10068-013-0122-9.

Savarese M, De Marco E, Sacchi R. 2007. Characterization of phenolic extracts from olives (Oleaeuropaea cv Pisciottana) by electrospray ionization mass spectrometry. Food Chem. 105, 761-770. http://dx.doi.org/10.1016/j.foodchem.2007.01.037.

Soni MG, Burdock GA, Christian M-S, Bitler C-M, Crea R. 2006. Safety assessment of aqueous olive pulp extract as an antioxidant or antimicrobial agent in foods. Food Chem. Toxicol. 44, 903-915. http://dx.doi.org/10.1016/j. fct.2006.01.008.

Sousa A, Ferreira ICFR, Barros L, Bento A, Pereira J-A. 2008. Effect of solvent and extraction temperatures on the antioxidant potential of traditional stoned table olives "alcaparras". Lebensm. Wiss. Technol. 41, 739-745. http://dx.doi. org/10.1016/j.lwt.2007.04.003.

Sroka Z, Cisowski W. 2003. Hydrogen peroxide scavenging, antioxidant and anti-radical activity of some phenolic acids. Food Chem. Toxicol. 41, 753-758. http://dx.doi.org/10.101 6\%2Fs0278-6915\%2802\%2900329-0.

Sun T, Tanumihardjo SA. 2007. An Integrated Approach to Evaluate Food Antioxidant Capacity. J. Food Sci. 72, 159-165. http://dx.doi.org/10.1111/j.1750-3841.2007.00552.x.

Velkov ZA, Kolev MK, Tadjer AV. 2007. Modeling and statistical analysis of DPPH Scavenging activity of phenolics. Collect. Czech. Chem. Commun. 72, 1461-1471. http://dx.doi.org/ $10.1135 / \mathrm{cccc} 20071461$

Vinha AF, Ferreres F, Silva BM, Valentão P, Gonçalves A, Pereira JA, Oliveira M-B, Seabra R-M, Andrade PB. 2005. Phenolic profiles of Portuguese olive fruits (Oleaeuropaea L.). Influences of cultivar and geographical origin. Food Chem. 89, 561-568. http://dx.doi.org/10.1016/j.foodchem.2004.03.012.

Zhan Y, Hong Dong C, Yao Y-J. 2006. Antioxidant activities of aqueous extract from cultivated fruit- bodies of Cordycepsmilitaris (L.) Link in vitro. J. Integr. Plant. Biol. 48, 1365-1370. http://dx.doi.org/10.1111/j.1744-7909.2006.00345.x. 